\title{
Lost in space, lost in himself: Paul Auster's Ghosts and the postmodern city
}

\begin{abstract}
Ghosts, the second part of Paul Auster's The New York Trilogy, is generically classified as anti-detective fiction. The dominant setting of the novel, the urban space of New York and the observatory apartment located in it, is endowed with postmodern qualities, which leads to the transformation of the specificity of the investigation and its departure from one that is traditional. Whereas, traditionally, in detective fiction the dominant space, be it a locked room or a city, to mention a few, offers the sleuth clues necessary for solving the case, in the postmodern story of detection these clues are disorienting or meaningless. Hence, the primary aim of this article is to examine the interrelation between the dominating chronotope in the novel and the investigation led by the protagonist, Blue. I intend to prove how the surroundings contribute to the replacement of rational and objective judgment of the case with personal engagement. The article also aims at providing an overview of the transformations of urban space in detective fiction, which functions as the introduction to a further discussion.
\end{abstract}

Keywords: Auster, Ghosts, postmodern detective fiction, space, chronotope.

"The critical scene of the mystery is when the detective enters."

$\sim$ Maureen Johnson

\section{The evolution of urban space in detective fiction}

Referring to the research on the significance of space in detective fiction, David Schmid argues that a great majority of criticism "engages with the role of space in crime fiction in a relatively passive manner, which means that houses, suburbs, cities and so on are treated merely as background or setting rather than as determinative forces" (2012: 7-8). However, it must be noted that from the very beginnings of detective fiction, the dominant space - borrowing Mikhail Bakhtin's term, the major chronotope - does not only represent a dominating space that functions as the background for events.

1 Address for correspondence: Wydział Humanistyczny, Maria Curie-Skłodowska University, Plac Marii Curie-Skłodowskiej 4A, 20-031 Lublin, Poland. E-mail: julia.kula@poczta.umcs.lublin.pl 
As Bakhtin expounds, chronotopes "are the organizing centers for the fundamental narrative events in the novel. The chronotope is the place where the knots of narrative are tied and untied... to them belongs the meaning that shapes the narrative" (1981: 250). Chronotopes are rigidly organised structures that specifically shape the run of the action and determine primary themes and motifs prevalent in the genre.

Looking at the recurrent chronotopes in detective fiction, apart from the locked room introduced by Poe and the country house prevalent, for instance, in Agatha Christie's fiction, another spatio-temporal continuum, modelled by Arthur Conan Doyle in Sherlock Holmes stories, is the city. Immersed in urban space, the detective seeks meaningful clues that would enable him to decipher the narrative of the crime or the mystery. Hence, in traditional detective fiction, the chronotope of the city functions as a map on which diverse elements "are the guardians of some secret... Every twist of the road is like a finger pointing to it.... there is no stone in the street and no brick in the wall that is not actually a deliberate symbol - a message from some man, as much as if it were a telegram or a postcard. (Chesterton 1901: 75)". The city in the earliest representatives of detective fiction can be compared to a map on which diverse clues are scattered. As Christopher Pittard points out, modernism that brought the emergence of detective fiction is associated with " $[\mathrm{t}]$ he collapsing of urban experience into an overwhelming collage of signs (both semiotically and literally)" (2010: 113), which is accentuated in the portrayal of the dominant chronotope from that period. When put together and deciphered, these signs create a coherent narrative of the committed crime.

The new variant of detective fiction that was initiated in America in the early 1920s - the hard-boiled one - predominantly redefined the representation of urban space in the genre. Contemporary problems, such as "civic and corporate corruption" (Pepper 2010: 143), capitalism, "endemic violence, and the remoteness of institutionalized law from any broader concept of justice" (Horsley 2005: 6), brought about by new circumstances, were the focal point of the then emerging convention. Urban space was no longer seen solely as a guardian of secrets, as in the traditional detective novel. The modern city, serving as the dominant chronotope in the genre, "becomes the wasteland", “a man-made desert or cavern of lost humanity" (Cawelti 1977: 155) to which the detective is not able to restore any order to, as was the case in traditional and classical stories of detection. Its physical construction reveals negative qualities of space as "an intractable, uncontainable, ultimately unknowable terrain, to be grasped only in a fragmentary way" (Horsley 2005: 71). Apart from the impossibility to fully comprehend what is inscribed in the cityscape, the private eye has to confront the unfavourable circumstances that await him in the city. As such, urban space "threatens a protagonist's sense of a discrete self, his powers of understanding, and his physical safety" (Horsley 2005: 71). 
As it has been mentioned before, the dominant chronotope does not represent the passive background, but actively shapes the narrative. Hence, there exists a close interdependence between the specificity of urban space in particular variants of the genre and the figure of the detective. The spatial image of the world in detective fiction - in this case the city - "on the one hand... is created by man, and on the other, it actively forms the person immersed in it" (Lotman 1990: 204). In traditional stories of detection, the chronotope "called for a cultural figure with particular expertise in reading such signs and in disregarding irrelevant information" (Pittard 2010: 113). These signs, not obvious and immediately visible, have to be collected and put into one, coherent whole by the detective whose rationality and excellent skills of deduction are instrumental in unravelling the mystery. As Jerome Delamater and Ruth Prigozy accentuate, " $t]$ he power to solve mysteries is, of course, the fundamental-and, quite possibly, the onlyproperty that distinguishes all detectives of conventional mystery fiction" (1997: 33).

The new urban chronotope as shaped in the hard-boiled variant is associated with a diverse type of detective. The sleuth, although a professional one, is no longer portrayed "as a brilliant eccentric with transcendent powers of ratiocination but as an ordinary man" (Cawelti 1977: 145) with flaws and vices. The unfavourable circumstances that form the narrative require a new hero, "a loner, an alienated individual who exists outside or beyond the socioeconomic order of family, friends, work, and home" (Scaggs 2005: 59); a figure with his own moral and ethical codes that usually deviate from socially acceptable ones. Since the detective is no longer endowed with almost superhuman abilities, the nature of his quest also differs. As Scaggs observes, "there is little or no analysis of clues and associated analytic deduction. Rather, the hard-boiled detective's investigations, involving direct questioning and movement from place to place, parallel the sort of tracking down of a quarry" (2005: 59). As such, instead of an ordered process of detection, the investigation resembles an "adventure in search of a hidden truth" (Chandler 1944: 237), often replete with perilous situations and risky confrontations.

\section{Postmodern detective fiction}

Although there can be enumerated crucial differences between the dominant chronotopes and the construction of the private eye in the traditional story of detection and the hard-boiled variant, the fundamental formula is still based on the detective's inquiry leading to the solution. Yet, in the postmodern detective novel, which is the focal point of this article, the formulaic pattern is subject to some significant alterations not only in terms of space and characters, but also in terms of the formula itself, which makes the convention problematic to categorise. These reformulations result in some critics, such as Stefano Tani, perceiving the postmodern story of detection "not as the continuation of the genre but as a transgression of it, or as a mutation" (1984: 30). Other critics, such as Patricia Merivale or Susan-Elizabeth Sweeney emphasise its specificity, claiming that 
it is distinguished "by the profound questions that it raises about narrative, interpretation, subjectivity, the nature of reality, and the limits of knowledge" (1999: 1).

As is demonstrated by Tani, Merivale, Sweeney, or other critics, such as Michael Holquist, William V. Spanos, or Howard Haycraft, who have substantially contributed to the theorisation of the postmodern detective fiction, although the conventional roles or indispensable formulaic components are altered, the dominant ${ }^{2}$, borrowing Roman Jakobson's term, remains consistent with the principal premise of the genre. Even though not necessarily directed at finding the individual responsible for a transgression, the detective's investigation constitutes the focal point of the storyline. The anti-detective novels of Jorge Luis Borges, Alain Robbe-Grillet, or Vladimir Nabokov, to name a few, foregrounded and revolved around matters such as the question of identity, ontological concerns about the nature of reality, or the relativity of space-time. Since then, trends initiated by these early writers have been applied and further developed in representatives of detective fiction of postmodern writers, such as Peter Ackroyd, Julian Barnes, Donald Barthelme, Umberto Eco, Thomas Pynchon, and Paul Auster, whose Ghosts is the novel under examination in this article.

As in the case of the previously discussed generic variants of the story of detection, they are, to a great extent, affected by the dominant chronotopes (the city and diverse variations of enclosed areas) which share the features of postmodern places and spaces. Even though the pursuit of truth is still at the centre of the plot, in many cases, it is no longer a criminal investigation. Instead, an inquiry tends to take the form of a 'tail job', it is directed at seeking missing persons, sorting out identity problems, or seeking after an unattainable truth. As Patricia Merivale claims, amongst other common themes of the anti-detective novel there are: "the world, city, or text as labyrinth;... the ambiguity, ubiquity, eerie meaningfulness, or sheer meaninglessness of clues and evidence; [or]... the "man of the crowd", the double, and the lost, stolen, or exchanged identity" (1999: 8).

Although contemporary anti-detective fiction may be defined by diverse spatialities originating from its generic predecessors, the most dominant is that of urban space. Yet, in its portrayal, it is far from resembling the $19^{\text {th }}$ and early $20^{\text {th }}$ city of Poe or Doyle, - spaces filled with clues that must and can be fully comprehended. Rather, in its construction, the city is closer to the spaces that dominate hard-boiled conventions - a fragmentary and intractable construct, threatening the private eye in diverse ways. Postmodern cities frequently featured in detective stories written from the mid- $20^{\text {th }}$ century, as Nick Bentley maintains, are often depicted as "disorienting, labyrinthine

2 As Roman Jakobson explains, the dominant refers to "the focusing component of a work of art; it rules, determines, and transforms the remaining components. It is the dominant that guarantees the integrity of the structure" (1978: 6) of the work. In other words, it represents the major focus of the work; in detective fiction it is the sleuth's investigation that can be considered the dominant around which the whole plot is construed. 
dystopias" (2006: 176), decentralised and disordered constructions strengthening the sense of urban dislocation and confusion.

Since the city - the dominant chronotope in the genre - is no longer portrayed as a map offering clues, the figure of the detective also undergoes a change in resonance with the anti-detective convention. If in modernism, urban space was perceived as one that cannot be fully comprehended, in postmodernism this specificity is even more intensified. Despite their character, modern cities provided detectives with clues that could be put into a coherent whole when analysed properly. Postmodern urban spaces, on the other hand, have nothing meaningful to provide their explorers with, apart from an overwhelming sense of disorientation and intellectual doubt in the meaningfulness of their findings. Postmodern cities thus require a new protagonist, who fits into contemporary circumstances.

With the evolution of detective fiction, there can be observed a tendency to construct the private eye as a more ordinary character. The investigator loses supernatural deductive powers and does not rely solely on pure reason. Instead, the detective resembles an average individual who has the right to make mistakes and form wrong judgements. The postmodern private eye does not resemble the Poesque predecessors; rather, he seems to contain the echoes of the Golden-Age and hard-boiled characters - possessing the double in the criminal or being unable to be emotionally detached from the case. As Susan Rowland argues, "the detective always possesses an - Other, his uncanny double in the murderer, partly because the quarry is the focus of the detective's desire, his burning mental energy (Rowland 2010: 119), as is for the criminal. The investigator thus constitutes a complete reversal of the 'ideal' figure of the sleuth. His investigation represents not only a purely professional sphere of life since the private eye is both "physically and emotionally involved in his case" (Shiloh 2011: 41). The investigator from the anti-detective stories is the one who is not able to successfully terminate his quest due to the influence of surroundings and the meaningfulness of clues. In his search for answers, the postmodern sleuth switches between various identities, which testifies to the foundation that postmodernism tends to "challenge the notion of an essential self, a self that in the modernist period still was a unity" (Fokkema 1991: 72).

\section{Ghosts: when the investigation goes wrong}

Ghosts, which is the narrative under discussion, represents the second instalment of Paul Auster's world-famous The New York Trilogy. In comparison to the remaining books of the trilogy (City of Glass and The Locked Room), Ghosts seems to reflect the specificity of detective fiction the most accurately since the plot development resembles those from hardboiled stories of detection. Yet, even though the indispensable elements of the convention are retained as the detective engages in a tail job - the case characteristic for the hard-boiled variant - the construction of urban space exerts a negative influence on the 
private eye. The postmodern representation of the city emphasises that urban space is fragmented, often decentralised, and thus confusing. Difficulties that the private eye has with deciphering clues resonate with the postmodern premise that there exist "multiple truths, depending on the time and place" (Lessem \& Schieffer 2016: 274) as "postmodernism denies permanent, knowable truths about human nature" (Uba 2012: 46). As it is no longer possible to point to the reliability of one interpretation of clues over the other, investigators in anti-detective fiction are doomed to fail at their pursuits.

Taking into consideration the scope of the research into Ghosts, the story is usually discussed together with the remaining volumes of the trilogy. As The New York Trilogy has gained worldwide recognition as a masterful postmodern detective narrative, numerous critics and scholars have discussed it from diverse angles. To provide a few examples, Martin Brendan in Paul Auster's Postmodernity examines the trilogy in reference to the fundamental premises of postmodernism in literature. Mark Brown, on the other hand, adopts a spatial approach to the work, but interconnects it with common concerns of postmodernism, such as language and writing. Richard Swope's focal point in "Approaching the Threshold(s) in Postmodern Detective Fiction" is the motif of the missing persons in anti-detective fiction of Auster and other writers - a trope considered as representative of the postmodern genre. Carsten Springer, on the other hand, examines all three stories in reference to a motif common for postmodern detective fiction, namely the doppelgänger. Hence, although the scope of the scrutiny is wide since various aspects are tackled, Auster's work is analysed mainly in relation to either the tenets of postmodernism in literature or the generic implication of the anti-detective narrative.

However, as for the time being, no attention has been given to the interrelation between the genre and the dominant chronotope. Thus, the focal point of this article is going to be the representation of space, which may be regarded as postmodernist, and the way the setting affects the detectives and their quests. I intend to demonstrate how the dominant chronotopes - the city and the apartment located there - shape the protagonist's investigation, taking into account the basic premises of the postmodern detective novel. Hence, I shall prove that the city and a few places constituting the detective's semiotic map no longer provide the man with appropriate conditions and clues necessary for a successful termination of the investigation.

The protagonist of the narrative, Blue, is a professional and self-employed private eye, who is assigned a task by a mysterious client, White, to follow a man named Black and send him regular reports. In order to carry out his investigation, the man abandons his former life and commences his observation in the room opposite Black's apartment. His detective endeavour consists of following Black along the streets of New York and eavesdropping on him while the man is submerged in seemingly ordinary activities such as reading or writing. Not being content with the results of the investigation, the protagonist decides to directly confront Black using a range of disguises. From now on, 
all his actions are directed at unmasking Black's real motives and finding out who is responsible for the charade he has been engaged in. After stealing a manuscript from the observed man's house, Blue learns that it is only a pile of his own reports, which provokes an ultimate and fierce confrontation between the private eye and the subject of the investigation. Having brutally fought Black, the sleuth collects the pages of the man's book in order to read them in his room. With no commentary made on the content of the manuscript, Blue leaves the room in silence.

When the spatial organisation of any city is examined, what immediately draws attention is that "space is broken down into separate spaces, occupied by functions that are exercised within distinct spaces" (Lefebvre 1980: 214). The urban territory can, therefore, be seen in terms of Lotman's concept of the semiosphere - heterogeneous semiotic space defined by constant interactions between its centre and peripheries. The city in detective fiction functions as a theatre where the drama of the committed crime and its investigation are staged, where every constituent of space has its significance and intensifies the sleuth's inquiry. Hence, when urban space is perceived in terms of Lotman's semiosphere, the crime scene stands for the centre of the detective's semiotic map, enabling him to exercise his professional skills, whereas the city and its streets function as the periphery that might facilitate or decelerate the investigation. However, while such an assumption seems valid for the traditional stories of detection, a different space represents the centre in hard-boiled fiction, namely the detective's office. Whereas, traditionally, the crime scene stands for a place where the sleuth proves their skills, the office stands for a point of reference for their sense of identity defining their social position. However, in Auster's novel the centre seems not to be fixed.

As may be observed in Ghosts, Blue's urban map for the investigation consists of three main components - his office where he is familiarised with the case, the apartment from which Black is observed, as well as New York's streets. Whereas the peripheral part of his semiosphere stands for the open spaces in the city, the centre does not remain stable, but changes as the action develops. At the very beginning, the story resembles a typical hard-boiled narrative whose action starts in the detective's office - the man's central point of reference for his sense of professional identity.

Blue goes to his office every day and sits at his desk, waiting for something to happen. For a long time nothing does, and then a man named White walks through the door, and that is how it begins.

The case seems simple enough. White wants Blue to follow a man named Black and to keep an eye on him for as long as necessary. (Auster 1987: 133)

The order does not seem unusual as the protagonist is familiar with tail jobs - they constitute a part of his experience in the profession as "[w]hile working for Brown, Blue 
did many tail jobs" (Auster 1987: 133). Then, the protagonist is able to find a temporary centre in "a small studio apartment on the third floor of a four-story brownstone" (Auster 1987: 135) rented by White for the purpose of the investigation. However, although Blue's identity is still defined through his occupation, the provisional centre created for the sake of the investigation fails to provide him with a stable point of reference that serves to help him with the case. Thus, the man's urban map is limited to the openness of streets and the closeness of the apartment. "Although Blue occasionally ventures out of his room, he exists essentially in a hermetic space” (Russel 1990: 77), which renders the investigation unsuccessful.

Taking into consideration the evolution of the dominant space in detective fiction, there can be observed a shift from one facilitating the process of detection to one confusing it, and defined by "randomness, revolt, deformation. The latter alone subsumes a dozen current terms of unmaking: decreation, disintegration, deconstruction, decenterment, displacement, difference, discontinuity, disjunction, disappearance, decomposition, de-definition" (Hassan 1983: 9). Both, the relatively open space of New York and the closed space of Blue's hideout are deconstructed and disintegrated versions of the traditional notions of space and place. The differentiation between space and place becomes blurred, as delineated, for instance, by Yi Fu-Tuan (Space And Place: The Perspective of Experience), Tim Cresswell (Place: A Short Introduction), or Irwin Altman (Place Attachment). These differences are still retained on the most fundamental level when the opposition between the public and the private, and the openness and the enclosure is concerned. Nevertheless, the reformulation is well-noticeable in connotations traditionally ascribed to space and place. As postmodern characteristics are attached to them, the difference is erased, as both the city and the apartment evoke in the protagonist, the sense of disorientation, and hopelessness, which, in turn, are defined by the lack of any stable points of reference.

For the protagonist, the central part of the city - the observatory room - proves not to be sufficient to work out the object of the tail job. Just the very first day of conducting his surveillance turns out to test his professional skills as the current predicament seems to be unfavourable for the man. The enclosed space of the flat clearly does not serve Blue as he feels trapped there:

So it goes for the rest of the evening, with Black reading and Blue watching him read. As time passes, Blue grows more and more discouraged. He's not used to sitting around like this, and with the darkness closing in on him now, it's beginning to get on his nerves. He likes to be up and about, moving from one place to another, doing things.... Now, when he himself is the boss, this is what he gets: a case with nothing to do. For to watch someone read and write is in effect to do nothing. (Auster 1987: 137) 
Sitting in a room is thus perceived as a fruitless occupation since it contributes to Blue's incapability to obtain an insight into Black's predicament and possible intentions. The more time spent on observing the suspect's quotidian activities, the more frustration grows inside the protagonist. Instead of possible clues that would guide him down the right path, the sleuth is given meaningless hints that do not contribute to the professionality of the reports.

The circumstances have their immediate reflection in the function of the language for Blue. In his previous jobs, his reports were based on pure objectivity and reliance upon what had been seen and experienced: "His method [was] to stick to outward facts, describing events as though each word tallied exactly with the thing described, and to question the matter no further. Words [were] transparent for him, great windows that stand between him and the world" (Auster 1987: 144). Words thus were assigned clear meaning as there used to exist a one-to-one relation between signifiers and things they referred to. Hence, "[i]n every report he has written so far, action holds forth over interpretation.... The report confines itself to known and verifiable facts, and beyond this limit it does not try to go" (Auster 1987: 144). However, Black's case puts Blue closer to the post-structuralist view of the language; its function as the window through which the world can be seen is no longer valid. Rather, the world and "the human subject [are] entirely constructed by the discourses in which [they are] situated" (Lodge 2002: 133). Thus, "Blue is bound to experience the (postmodern) inadequacy of language to really contain the world" (Espejo 2013: 165) as words he uses in his reports do not serve their expected function. Even his observations disappoint him as the man is unable to find any coherence in them:

There is the notebook, of course, but when he looks through it to see what he has written, he is disappointed to find such paucity of detail. It's as though his words, instead of drawing out the facts and making them sit palpably in the world, have induced them to disappear. (Auster 1987: 144-145)

Blue's notes do not reflect the observed reality and the written down words lose their transparency. As such, instability and the disorienting character of space has its immediate reflection in language. The more Blue is lost in the case, the more difficulties arise, which points to the insufficiency of language to capture reality.

Thus, in Ghosts, the echoes of the post-structuralists' stance are well-noticeable in the protagonist's struggles with writing the reports. Referring to the post-structuralist approach to language, Donald Ellis argues that it is "obsessed with instability and variability of meaning. Certainly, when language is viewed this way, concepts such as "truth," "knowledge," and "reality" lose their value" (1991: 219). Fluctuations of significance stressed by post-structuralists are closely related to the postmodernists' distrust 
concerning the existence of one, unquestionable truth. "Poststructuralists very much want to cling to the idea that reality exists in the human mind and nowhere else" (Ellis 1991: 219) and, hence, language is an insufficient device to express it objectively. As no meaning can be uncovered, Blue is unable to use his existing knowledge to formulate proper findings for White, which strengthens his impression that words instead of reflecting reality, mask it and, consequently, create the detective's own, subjective image of the situation.

Since the enclosed space reinforces the protagonist's confabulations and makes it more difficult to maintain objectivity, it would seem that the open space of Manhattan streets would be the proper surroundings to shed new light on the case. However, the New York that Blue experiences while following Black does not resemble a typical 'map' on which pieces of the puzzle are scattered, but exerts on him a similar influence as does the room. The man's every walk is imbued with qualities that Ihab Hassan (1983: 9) identifies with postmodern spaces - disintegration, displacement, or discontinuity. The streets and physical components of the city thus become only "a man-made construct, ambitious in its conception, but not always fulfilling its intended purpose" (Varvogli 2001: 31) since, paradoxically, the more Blue engages in the investigation, the more distanced from the task he becomes.

Consequently, New York makes it impossible to properly fulfill the role of the sleuth as Blue begins:

to lead the semblance of an independent life. At first he is not very daring in what he allows himself to do, but even so he considers it a kind of triumph, almost an act of bravery. Going outside, for example, and walking up and down the block. (Auster 1987: 155).

Solitary strolls, which are just the very beginning, detach the protagonist from the case as "[1]ittle by little, he becomes more bold in his strayings from Black" (Auster 1987: 156). Additionally, more and more often the centre of his attention is directed not at the case itself, but at his personal recollections and experiences. When he follows Black along the Brooklyn Bridge, for instance, he "can see himself holding his father's hand and walking at his side, and as he hears the traffic moving along the steel bridgeroad below" (Auster 1987: 146). However, the fundamental problem for Blue arises when his personal attachment to urban space is more intense and, as a result, obscures his responsibilities towards White. Such circumstances lead to the lack of proper grounding in the case, which results in a disturbance of the investigation. Yet, the detective remains aware of the disturbing predicament as "he wonders why he has turned so sentimental, why all these thoughts keep coming to him, when for so many years they have never even occurred to him" (Auster 1987: 149). 
While accompanying Black along the streets of New York like an invisible shadow, Blue is subject to the feeling of disorientation. Pointless walks through the labyrinthine cityscape leave him with the conclusion that "no rhyme or reason can be read into anything that's happened so far" (Auster 1987: 150) since he cannot find any stable coordinates to rely on. Contemplations of a personal nature supersede rational deductions. Hence,

[h]is routine job on following what White has required of him gradually creates for him a world which deprives him of his critical thinking as to the reliability of the information he received and the reality of the job he was offered. He suspects and tries to resolve his uncertainties with endless narratives on the reality of his situation but finds himself drowned with no valid, identifying story and an increasingly debilitated consciousness. (Torkamaneh 2015: 307)

As such, a typical, reasonable, and objective world of detective fiction changes into one based on creativity, subjectivity, and emotions. The chronotopes dominating in Ghosts are thus not governed by intellect, but by imagination, which has its reflection in the identification of the private eye with the writer. Consequently, "the role of detective merges with the role of the writer. We understand that both writer and detective make sense of the chaos of words, and of the world" (Jones \& Ells 2011: 633). Writing reports to White, Blue is given power to re-create a possible chain of events leading to the act of undercover surveillance. Yet, the fundamental difference is that the surroundings in postmodern detective fiction make it impossible for the detective to properly interpret signs and restore order.

In Ghosts "the breakdown of the detection process is always accompanied by the breakdown of the self" (Lewis 1994: 60), which is reflected not only in an unstable identity, but also in the existence of a double. Its manifestation is primarily maintained on the level of the uncanny relation between Blue and Black:

There are moments when he feels so completely in harmony with Black, so naturally at one with the other man, that to anticipate what Black is going to do, to know when he will stay in his room and when he will go out, he need merely look into himself [...]. On the other hand, not all moments are like these. There are times when he feels totally removed from Black, cut off from him in a way that is so stark and absolute that he begins to lose the sense of who he is (Auster 1987: 153)

The unconscious identification with Black leads Blue to experience the sense of intimacy with the observed. Looking through the window thus can be perceived as looking into the mirror - the observed evolves into the man's own reflection as "in spying out at Black across the street, it is as though Blue were looking into a mirror, and instead of merely 
watching another, he finds that he is also watching himself" (Auster 1987: 142). As such, the men become 'identical' in pursued activities and predicament - the act of surveillance becomes for Blue the observation of himself since "Black is doing exactly the same thing: like Blue, he sits in a room, takes notes, reads, and looks out of his window" (Varvogli 2001: 49). Blue's confidence is thus undermined as the resemblance of Black's actions becomes disturbing. Although there exists no substitution of selves in the Freudian ${ }^{3}$ understanding, the man's true self as a detective is substantially weakened. He oscillates between different states - a complete identification, almost unification with the other man and, when distanced from him, a sensation of being displaced.

Whereas the enclosed space of the room contributes to the emergence of the doppelgänger as Blue finds his mirror image in Black, the open space of New York reveals a different manifestation of the double. The doubling here refers to the roles Blue and Black assume or are given as they become interchangeable. As it turns out, Black's task is also "to watch someone... and send in a report about him every week. Just that. Watch this guy and write about it. Not one damned thing more (Auster 1987: 177). It points to a presumed reversal of roles - the observed is, in fact, the observing, and the other way around. At one point, Blue notices that "[i]t seems perfectly plausible to him that he is also being watched, observed by another in the same way that he has been observing Black" (Auster 1987: 165). As each of the men is in possession of both roles, it strengthens Blue's perception of Black as his mirror image and an uncanny double. All this time when he pursues his 'tail job', believing that it is a case commissioned by White, where Blue observes Black and creates reports, the object of his inquiry follows exactly the same path. As a result, the unconscious identification with the observed leads to the detective losing his sense of self. He does not realize that by engaging in the case, his sense of existence has become dependent on the observed. When the protagonist wants to know whether the man watched by Black knows about this, he replies:

Of course he knows. That's the whole point, isn't it? He's got to know, or else nothing makes sense.

Why?

Because he needs me, says Black, still looking away. He needs my eyes looking at him. He needs me to prove he's alive. (Auster 1987: 178)

\footnotetext{
3 Referring to the uncanny identification between two individuals, Freud maintains that "a person may identify himself with another and so become unsure of his true self; or he may substitute the other's self for his own. The self may thus be duplicated, divided and interchanged" (1919: 141-142). More in: Freud (1919).
} 
Thus, the men cannot exist without each other - feeling the second's eyes on themselves, having the impression of being constantly observed proves that they have become merely ghosts of their former selves. Both Blue and Black live to watch and to be watched and their mutual 'unification' is another manifestation of having become doppelgängers.

Yet, the urban space of New York functions not only as the stage for the doubling between the detective and the 'culprit', but it is also where Blue's experimentations with identity occur. As a typical postmodern private eye, the man "possessing all of the marginality, but none of the self-confidence of the classical detective, he spends much of the time walking in circles through streets that look alike, adopting roles for himself to boost his confidence" (Merivale \& Sweeney 1999: 110). Being unable to piece together any meaningful clues, the detective resorts to various disguises supposed to help him, such as Jimmy Rose, an old beggar, or the Fuller brush man. Undercover encounters with the subject of the investigation seem to, indeed, boost his confidence as they shed some light on Blue's complicated situation and his actual role in the whole charade. Conversations thus reinforce the protagonist's belief that "no more disguises will be needed. The next step is inevitable, and the only thing that matters now is to choose the right moment" (Auster 1987: 182). As such, the sleuth's ultimate decision leads to the ending typical for hard-boiled stories of detection since, as Cawelti points out, in this convention the "story usually ends with a confrontation between detective and criminal" (1977: 143). However, the direct confrontation does not lead to any solution as the postmodern story of detection emphasizes the "rebuttal of any central resolution or abiding truth" (Smith 2002: 33).

\section{Conclusion}

Discussing the specificity of postmodern detective fiction, Patricia Merivale and SusanElizabeth Sweeney emphasise that "[a] metaphysical detective story is a text that parodies or subverts traditional detective-story conventions - such as narrative closure and the detective's role as surrogate reader" (1999: 2). The foregrounding of issues typical for postmodernism, such as the limits of the detective's understanding, uncertainty, or the impossibility of discovering one, unquestionable truth, leads to the significance of the criminal investigation being only subtly delineated. As Michael Holquist points out while referring to the transformation in the character of the inquiry, "[i]f in the detective story death must be solved, in the new metaphysical detective story it is life which must be solved" (1971: 155). It is worth pointing out, however, that there exists a close interrelation between the concerns of the postmodern story of detection, the character of the investigation, or the specificity of the detective and the dominant chronotope(s) the city or/and enclosed spaces located in urban space. As such, it is the prevalent space and its nature that shape the case, the detective, as well as the major concerns. 
In detective fiction before postmodernism, temporal relations applicable to stories of detection tend to create

two separate stories: the story of the crime and the story of the investigation. Narrative presentation combines them in a specific manner. In whodunits, the story of the crime belongs to the past and is - because hidden - absent from the present, whereas the story of the investigation happens in the present, its main function being the uncovering of the story of the crime. (Pyrhönen 2010: 49)

Hence, the dominant space, be it the city or a place in the city, for instance, offers appropriate conditions for these two temporal dimensions to meet. However, in Ghosts the main chronotopes no longer create conditions favourable for the successful termination of the investigation due to the story of the past not being, in fact, related to any crime. It is observable that "Blue's detective quest thus differs from that of the traditional sleuth in two crucial respects: it is static and has no apparent purpose.... A detective enquiry with no telos, no crime to investigate, is voided of directionality and movement" (Shiloh 2012: 60). Neither the urban space of New York nor the observatory room enable Blue to professionally approach the case; instead, they contribute to Blue's sense of disorientation and confusion. Whereas the enclosed space of the room and the monotonous act of observation result in the protagonist's mind wandering off from the investigation, the streets of New York cause the sleuth to "experience loneliness, disconnection and personal disintegration" (Brown 2007: 34). Blue proves to be incapable of maintaining a healthy balance between his private life and work; his weakness generates conditions that make the protagonist get "emotionally caught in the net of his detecting effort and is torn apart between the upsurge of feelings and the necessity for rationality" (Tani 1984: 42). Hence, as may be expected from the characters in postmodern detective novels, the man immersed in a space offering neither meaningful clues nor unquestionable truths, experiences the dispersal of his identity, visible, for instance, when he identifies with Black as his double.

\section{References}

Auster, P. 1987. The New York Trilogy. London: Faber and Faber.

Bakhtin, M. 1981. Forms of time and of the chronotope in the novel. The Dialogic Imagination: Four Essays. In: M. Holquist (ed.), trans. C. Emerson \& M. Holquist, 84-258. Austin: University of Texas Press.

Bentley, N. 2006. Postmodern cities. The Cambridge Companion to the City in Literature. In: K. McNamara (ed.), 175-187. USA: Cambridge University Press.

Brown, M. 2007. Paul Auster. Manchester/New York: Manchester University Press. 
Cawelti, J. 1977. Adventure, Mystery, and Romance. Formula Stories as Art and Popular Culture. Chicago: University of Chicago Press.

Chandler, R. 1944. The simple art of murder. The Art of the Mystery Story. In: H. Haycraft (ed.) 1947, 222-237. New York: Biblo and Tannen.

Chesterton, G. K. 1901. A defence of detective stories. The Art of the Mystery Story. In: H. Haycraft (ed.) 1947, 3-6. New York: Biblo and Tannen.

Delamater, J. H. \& Prigozy, R. 1997. Theory and Practice of Classic Detective Fiction. Westport, CT: Greenwood Press.

Ellis, D. G. 1991. PostStructuralism and Language: NonSense. Communication Monographs, vol. 58, no. 2: 213-224.

Espejo, R. 2013. Coping with the postmodern: Paul Auster's New York Trilogy. Journal of American Studies, vol. 48, no. 1: 147-171.

Fokkema, A. 1991. Postmodern Characters: A Study of Characterization in British and American Postmodern Fiction. Amsterdam: Rodopi.

Freud, S. 1919. The Uncanny, trans. David McLintock. 2003. London/New York: Penguin Books.

Hassan, I. 1983. Desire and dissent in the postmodern age. The Kenyon Review, vol. 5, no. 1: 1-18.

Holquist, M. 1971. Whodunit and other questions: Metaphysical detective stories in post-war fiction. New Literary History, vol. 3, no. 1: 135-156.

Horsley, L. 2005. Twentieth-Century Crime Fiction. Oxford: Oxford University Press.

Jakobson, R. 1978. The Dominant. Readings in Russian Poetics. In: L. Matejka \& K. Pomorska (eds.), 82-7. Ann Arbor: Michigan Slavic Publications.

Jones, G. \& K. Ells. 2011. Chaos and complexity in Paul Auster's New York Trilogy. Restoring the Mystery of the Rainbow (2 Vols.), 627-639. Leiden: Brill Rodopi.

Lefebvre, H. 1980. Space and Mode of Production. State, Space, World: Selected Essays. In: N. Brenner \& S. Elden (eds.), G. Moore, N. Brenner \& S. Elden (trans.), 210-223. 2009. Minneapolis: University of Minneapolis Press.

Lessem, R. \& A. Schieffer. 2016. Integral Research and Innovation: Transforming Enterprise and Society. Florida: CRC Press.

Lewis, B. 1994. The strange case of Paul Auster. Review of Contemporary Fiction, vol. 14, no. 1: 53-61.

Lodge, D. 2002. Consciousness and the Novel. Harvard University Press.

Lotman, Y. 1990. Universe of the Mind: A Semiotic Theory of Culture, trans. A. Shukman. 2001. Bloomington: Indiana University Press.

Merivale, P. \& S. E. Sweeney. 1999. Detecting Texts: The Metaphysical Detective Story from Poe to Postmodernism. Philadelphia: University of Pennsylvania Press.

Pepper, A. 2010. The 'hard-boiled' genre. A Companion to Crime Fiction. In: Ch. Rzepka \& L. Horsley (eds.), 140-151.United States: John Wiley \& Sons. 
Pittard, Ch. 2010. From sensation to the Strand. A Companion to Crime Fiction. In: Ch. Rzepka \& L. Horsley (eds.), 105-116. United States: John Wiley \& Sons.

Pyrhönen, H. 2010. Criticism and theory. A Companion to Crime Fiction. In: Ch. Rzepka \& L. Horsley (eds.), 43-56. United States: John Wiley \& Sons.

Rowland, S. 2010. The "classical" model of the golden age. A Companion to Crime Fiction. In Ch. Rzepka \& L. Horsley (eds.), 117-127. United States: John Wiley \& Sons.

Russell, A. 1990. Deconstructing The New York Trilogy: Paul Auster's anti-detective fiction. Critique: Studies in Contemporary Fiction, vol. 31, no. 2: 71-84.

Scaggs, J. 2005. Crime Fiction (The New Critical Idiom). London: Routledge.

Schmid, D. 2012. From the locked room to the globe: Space in crime fiction. Cross-Cultural Connections in Crime Fictions. In: V. Miller \& H. Oakley (eds.), 7-23. London: Palgrave Macmillan.

Shiloh, I. 2011. The Double, the Labyrinth and the Locked Room: Metaphors of Paradox in Crime Fiction and Film. New York: Peter Lang.

Shiloh, I. 2012. Paul Auster and Postmodern Quest On the Road to Nowhere. New York: Peter Lang.

Smith, H. 2002. 'A labyrinth of endless steps': Fiction making, interactive narrativity, and the poetics of space in Paul Auster's City of Glass. Australasian Journal of American Studies, vol. 21, no. 2: 33-51.

Tani, S. 1984. The doomed detective: the contribution of the detective novel to postmodern American and Italian fiction. Illinois: Southern Illinois University Press.

Torkamaneh, P. 2015. Fractured selves and the illusion of communication: Paul Auster's Ghosts as a Reflection of the Hyperreal. The Explicator, vol. 73, no. 4: 306-311.

Uba, L. 2012. Postmodern Psychology of Asian Americans: Creating Knowledge of a Racial Minority. Albany, New York: SUNY Press.

Varvogli, A. 2001. The World That Is the Book: Paul Auster's Fiction. Liverpool University Press.

$* * *$

Julia Kula is a graduate assistant and a $\mathrm{PhD}$ candidate at Maria Curie-Skłodowska University. She holds a Master's Degree in British literature. Her PhD thesis explores the interrelation between literary genres and defining chronotopes in Paul Auster's fiction. She has participated in various conferences in which she has presented papers concerning, but not limited to, Auster's novels. She has published on Auster's fiction and works of Neil Gaiman, Dmitry Glukhovsky, and Suzanne Collins, above all. Her main areas of academic interest include postmodernism, the evolution of generic conventions, the construction of urban space, as well as spatial semiotics. 